\title{
Grandes Vinos: The "Over the Rainbow” Initiative \& Corporate Philanthropy During a Tragedy
}

\author{
Rosana Fuentes-Fernández ${ }^{1}$ \\ 1 University of León \\ Keywords: spain, pandemic, crisis management, wine cooperatives, social responsibility, wine sustainability \\ https://doi.org/10.26813/001c.22073
}

Wine Business Journal

Vol. 4, Issue 2, 2020

\begin{abstract}
From the start of the pandemic, Grandes Vinos, the largest winery in the autonomous community of Aragón in the province of Zaragoza and one of the 60 largest wine producers in Spain, directed its efforts toward the healthcare sector with a philanthropic initiative entitled "Over the Rainbow." The company believed the "Over the Rainbow" initiative represented one of the best opportunities to make the biggest possible societal impact in these difficult times. It would donate the proceeds from sales of wine to support the elderly and a COVID-19 vaccine development through partnerships with Médicos del Mundo and \#YoMeCorono respectively. This case study analyses the ways in which Grandes Vinos adapted to the "new normal" and how it immediately reacted to the pandemic by launching an initiative to simultaneously help the community and strengthen their brand.
\end{abstract}

In early March 2020, concern began to grow as news from Italy painted a grim picture of the spreading coronavirus pandemic. In Spain, COVID-19 cases started to mount, and within what seemed like days, hundreds of people were dying daily. On March 14, 2020, Spanish President Pedro Sánchez triggered a state of alarm, placing the country into lockdown for 15 weeks. The country would ultimately emerge on June 21, 2020 into what would be its "new normal."

In order to contain the expansion of the virus and flatten the death and infection curves, the Spanish government implemented a range of policy responses, including: social distancing measures, obligatory wearing of masks in public, restricting domestic and international travel, border closures, stay-at-home orders, and placing limitations on the size of gatherings.

The lockdown also triggered the closure of all bars and restaurants for three months, which directly affected vital sales channels for wineries. With people under stay-athome orders in their respective countries, wine producers around the world had to adapt to their new reality. Wineries, for instance, had to continue with their work; vineyards needed to be attended to in order for grapes to be harvested. Faced with this situation, wineries, as part of their communities, decided to help in different ways. Various projects were undertaken to assist those affected.

From the start of the pandemic, Grandes Vinos, the largest winery in the autonomous community of Aragón in the province of Zaragoza and one of the 60 largest wine producers in Spain, directed its efforts toward the healthcare sector with a philanthropic initiative entitled "Over the Rainbow." The company believed the "Over the Rainbow" initiative represented one of the best opportunities to make the biggest possible societal impact in these difficult times. It would donate the proceeds from sales of wine to support the elderly and a COVID-19 vaccine development through partnerships with Médicos del Mundo and \#YoMeCorono respectively. This case study analyses the ways in which Grandes Vinos adapted to the "new normal" and how it immediately reacted to the pandemic by launching an initiative to simultaneously help the community and strengthen their brand.

\section{HEALTHCARE PROBLEMS CREATED BY COVID-19 IN SPAIN}

The coronavirus crisis served as a dividing line between a former reality and the "new normal." For years, Spanish politicians asserted that, "Spain had the best healthcare in the world," and Spanish people were very proud of it. Recently, the healthcare system faced increasingly frequent budget cuts. Healthcare workers went on strike to protest the budget cuts and warned of serious deficiencies in the country's hospitals. These strikes revealed the Spanish healthcare system had been broken long before the impacts of COVID-19.

When COVID-19 hit, the deficiencies in the healthcare system were apparent. Healthcare workers suffered from inadequate or non-existent equipment. For instance, personal protective equipment (PPE) was in limited supply. Some healthcare workers resorted to using trash bags to protect themselves. There was also a short supply of ventilators, forcing hospital staff to choose which patients would receive ventilation and who would not. Many of the healthcare workers faced death themselves, given the high infection rate among frontline workers.

Spain had one of the world's highest coronavirus mortality rates, with over 28,406 people having died as of July 14, 2020 ("Últimos Datos Oficiales de Covid-19 En España," 2020). Healthcare workers' sacrifices were put on full dis- 
play for the world to see, as many gave their lives to save others. Their plight demonstrated the importance of refraining from making cuts to the public healthcare budget and system.

\section{A CORPORATE PHILANTHROPY-BASED INITIATIVE FOR SOCIETY}

\section{Corporate philanthropy: To do well by doing good}

Firms were expected to pursue their economic missions within the framework of the law and decide whether they wanted to go beyond what was required by law based on a direct economic or technical interest (Davis, 1960). Thus, enterprises had ethical and discretionary responsibilities beyond what was legally mandated (Carroll, 1979). For that reason, corporate social responsibility (CSR), had been defined as comprising four key components: economic, legal, ethical, and philanthropic. Exhibit 1 depicts these four components in Carroll's CSR pyramid.

Corporate philanthropy involved gifts or monetary contributions given by corporations to social and charitable causes, such as those associated with education, culture, the arts, minorities, health care, and disaster relief (Godfrey, 2005; Seifert et al., 2004). As Caroll explained, "philanthropy encompasses those corporate actions that are in response to society's expectation that businesses be good corporate citizens" (Carroll, 1991, p. 42).

Corporate philanthropy sought to address underlying issues to effect a tangible positive change in societal conditions-in this case, those that accompanied the COVID-19 pandemic. Another key aspect of the definition of corporate philanthropy was that the resources donated may consist of money, goods, time, training, or use of facilities or services, usually over an extended period and regarding a defined objective. Today, "doing well by doing good" is the prevailing motive behind corporate giving (File \& Prince, 1998; Sánchez, 2000; Smith, 1994). In other words, a company could make a profit and make the world a better place at the same time.

\section{Why philanthropy is important in a crisis}

As far as economic considerations were concerned, our century would be remembered, perhaps more so than for any other event, for how firms had been forced to adapt to the new reality arising out of the COVID-19 pandemic. Although there have been several epidemics and pandemics since the 1980s, none had such major consequences for the global economy as had COVID-19 (Gössling et al., 2020). Human mobility and a lack of mass testing for asymptomatic individuals had intensified the global spread of the virus.

In the COVID-19 era, customer safety and well-being were particularly salient components of CSR, given changes in people's daily routines (Wen et al., 2020). Corporate social responsibility initiatives were usually encouraged to improve social well-being with or without a direct benefit to corporate financial well-being.

According to instrumental stakeholder theory (Jones, 1995), whether or not companies should invest in CSR dur-

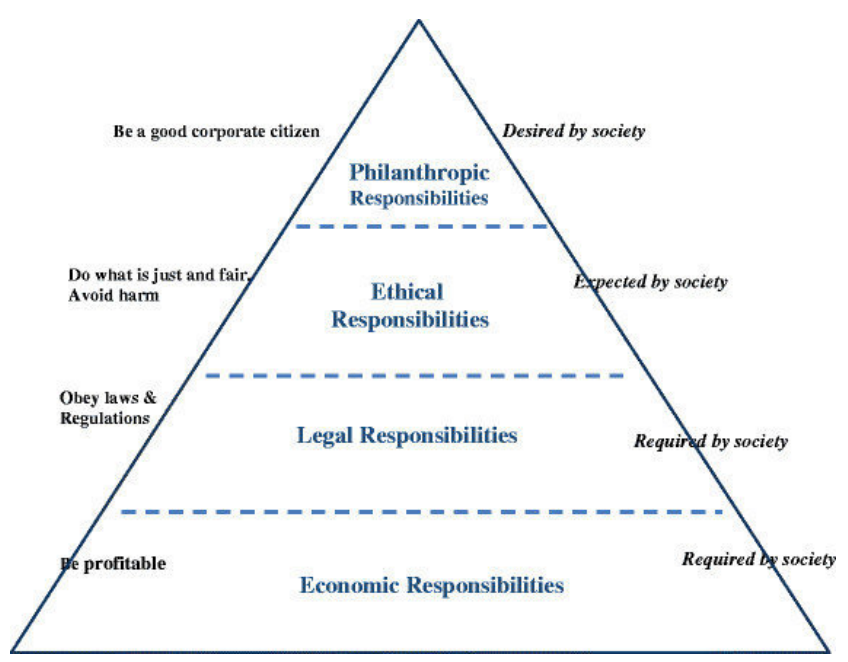

\section{Exhibit 1: Carroll's Corporate Social Responsibility Pyramid}

Source: Carroll, A. B. (1991). The Pyramid of Corporate Social Responsibility: Toward the Moral Management of Organizational Stakeholders. Business Horizons, 34(4), 39-48. doi:10.1016/0007-6813(91)90005-g

ing difficult times remains controversial. Now more than ever, our society needed assistance, and some firms were accomplishing this through CSR initiatives. Although potentially costly, operations-related CSR, such as Grandes Vinos' "Over the Rainbow" initiative, might also increase the firm's value (Lee et al., 2013).

\section{COMPANY BACKGROUND}

Grandes Vinos was founded in 1997 with an innovative business model. It combined winegrower cooperatives with an Agrarian Transformation Entity (ATE). Over 700 families of winegrowers had united to form Grandes Vinos, combining their hard work and knowledge to create wines that were both traditional and innovative. The new company's mission was to make vineyard cultivation in Cariñena (a village in the province of Zaragoza, in the autonomous community of Aragón) sustainable and profitable through both the production and commercialization of the region's wine. It established export and consumer markets as its main growth strategy and principal priority.

\section{The land, grapes, and wines}

Since its beginnings, Grandes Vinos laid its strategic foundations on quality, innovation, and commitment to the surroundings and the environment. Grandes Vinos managed the complete cycle of vineyard production and sales of its wines. It believed in innovation, implementing new work systems and better control processes, from the vine onwards.

This company had the distinction of being the only winery with vineyards in the 14 municipal areas of the Campo de Cariñena Designation of Origin, which was what set it apart. Over 4,500 hectares of the vineyard proper were spread over the slopes of the Sierra de Algairén and Picos de Europa ranges of the Iberian Peninsula, between the Huerva and Jalón rivers. The vineyards made up one of the richest 
and most varied landscapes, with vineyards of different ages set at different heights between 320 and 850 meters above sea level. The vineyards were planted with indigenous Garnacha and Cariñena grapes in a range of soils and in varying climate conditions.

The winery achieved the following certifications: ISO 9001 (quality), ISO 14001 (environment), International Food Standard (IFS), the British Retail Consortium (BRC), and in 2015 had received the ECO-PROWINE European label that showed its commitment to the environment.

The winery's portfolio included Anayón, Corona de Aragón, and Monasterio de las Viñas, which were aimed at traditional markets; and Beso de Vino, El Circo, Hoy, and 3C, with a more modern focus. The portfolio stood out because of its high quality, its consistency over time, and its worldwide reputation for excellent value. Robert Parker's magazine, The Wine Advocate, described Grandes Vinos wines as "stunning values."

The company also produced a slightly sparkling wine, Iglup, in a white or rosé. The drinks, containing just 4.8 percent alcohol in bottles with a crown cap closure, were aimed to bring young people closer to the world of wine.

\section{Philanthropy}

Grandes Vinos also had an active program of corporate social responsibility. In 2007, it launched an initiative named "Vino Solidario" through which the company raised EUR 123,668 to benefit the Down's Syndrome Foundation in Zaragoza. In 2019, it obtained the Social Responsibility of Aragón Seal by the government of Aragón, a distinction that recognized corporate social responsibility and socially responsible practices. Moreover, the company was an ambassador for its land. It was linked to the Tourist and Convention Office in Zaragoza and worked with the government of the province of Zaragoza to play a role in promoting tourism in the area.

\section{Grandes Vinos' position in the market}

Grandes Vinos, the largest winery in the autonomous community of Aragon, was recognized for its innovation, quality, competitiveness, and service, with its commercial brands holding a growing position in national and export markets (Alimarket).

Grandes Vinos' average sales over the past three years included over 18 million bottles sold in more than 40 countries, representing an average revenue of more than EUR 30 million. The domestic market accounted for 35 percent of total revenue. The domestic Spanish market had underperformed as compared to prior years, with a decrease in revenue of 6.57 percent. The sharp drop in revenue due to the closure of the HORECA (hotel, restaurant, and catering) channel had not been fully offset by the significant increase of 23.61 percent in the retail distribution channel, which had led to an overall decline in the domestic market.

In general, Grandes Vinos distributed more of its products through the off-premises retail than it did through the on-premises (hotel, restaurant, and catering channel), which had allowed for an increase in export market revenue of 11.40 percent. Revenue from online sales of Grandes Vinos' products, exclusively available to those residing in

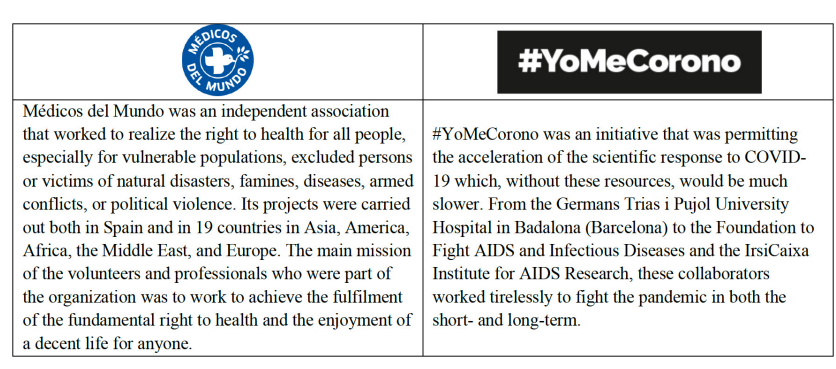

Exhibit 2: Médicos del Mundo and \#YoMeCorono

Source: https://www.medicosdelmundo.org/, https://www.yomecorono.com

mainland Spain and Portugal, were relatively minor in comparison, representing less than one percent of total revenue. Key countries that drove revenue growth in Q1 2020, include: Canada, the United Kingdom, and France. Countries that experienced decreases in revenue, include: Russia, Poland, Germany, Belgium, and the United States.

\section{THE “OVER THE RAINBOW” INTIATIVE}

The "Over the Rainbow" initiative was born out of Grandes Vinos' commitment to social responsibility and need as a company to support society during the COVID-19 crisis. Its philanthropic initiative consisted of the production of 20,000 bottles of wine to be sold with the goal of raising EUR 265,600 in proceeds, all of which would be donated to the fight against COVID-19. The company needed widespread support from hundreds of Grandes Vinos wine lovers to help them reach this goal. Grandes Vinos itself had committed to launching this initiative by making a direct donation of EUR 50,000 (Over the Rainbow, 2020).

The principal stakeholder involved in this initiative was society as a whole, as the funds raised would be invested in senior citizens' health care and COVID-19 vaccine research development. The company had also designed the initiative with its owners-the 700 families of winegrowers belonging to five wine cooperatives-in mind, together with the Aragonese government and Ibercaja and Bantierra, Aragon's two local food banks.

Grandes Vinos proposed that stakeholders support their elders by doing their part in the fight against COVID-19 through their purchase of one of its charitable wines. Grandes Vinos CEO José Antonio Briz said:

\footnotetext{
We are who we are thanks to our elders. Now, more than ever, it is our obligation to stand by them, as this group had been the most affected by the pandemic, in Spain as a whole but also in our region within our [winegrowing community], and that was the reason we've focused on them.
}

The full amount of the proceeds raised from the sale of the 20,000 bottles would be put toward fighting the pandemic. This would be accomplished on two equal fronts: by supporting society's most vulnerable group, the elderly, and by financing coronavirus vaccine research through two collaboration agreements with Médicos del Mundo and \#YoMeCorono, respectively (Over the Rainbow, 2020). See Exhibit 2 for details on Médicos del Mundo and \#YoMeCorono. 
In order to reach its EUR 265,600 goal, Grandes Vinos needed individuals and companies to purchase its products (shown in Exhibit 3), which were available in two formats. Grandes Vinos produced and had for sale 800 "Over the Rainbow Premium Packs," which included three bottles of Anayón and sold at EUR 200 per pack. Additionally, Grandes Vinos produced and had for sale 17,600 bottles of "Over the Rainbow Rosé," which sold for EUR 6 per bottle and was a new addition to its Monasterio de las Viñas line. These wines were only sold in Spain via the Grandes Vinos online store and through their partner, "Wine is Social" wine club.

Grandes Vinos employed another tactic to raise awareness of their initiative. They partnered with musicians to create an original song to attract attention on social media. The song, \#BrindisRainbow, was an original track inspired by the rainbow, an international symbol of unity, strength, and hope in the fight against this pandemic. Created by musical artists Briguel (@wearebriguel) from New York, it combined the voices of Alex Forriols (@alexforriols), Alessandro Campone (@donaleandrodelavega), Mandarina (@mandarina.music), and Luvie (@luvie.music) The musicians created a musical video with scenes of the artists and dance steps of Ana Morales (@anaenberlin) collaborating from the confinements of their homes in New York, Paris, Madrid, Berlin, Rome, and Rio de Janeiro. The song, video, and hashtag were shared on social media, and viewers we're encourage to collaborate, purchase, and enjoy the wines, and to also spread the word among their social networks.

In conceiving and carrying out this initiative, Grandes Vinos had aimed to integrate all of its stakeholders in one way or another: its owners and employees were proud of the initiative and to be a part of Grandes Vinos; the company had incorporated its suppliers as part of the initiative; it had also selected one of its customers, a wine club, Wine Social, to help distribute the wine; and it had been in contact with press and used social media to help spread the word regarding the initiative (José Antonio Briz, 2020).

\section{GRANDES VINOS' NEW STRATEGIES DURING COVID-19}

With the onset of COVID-19 and the worldwide closures, including bars and restaurants, Grandes Vinos faced immense challenges. José Antonio Briz determined the following areas would be the company's top priorities and focus: health and safety, finances, digital marketing and sales, and philanthropy. He summarized his company mandates:

Health and Safety:

- Safeguard employees' health in the workplace by adopting all necessary health and safety measures in the production department and allowing employees to work remotely. On March 16, 2020, the company informed all the employees of its safety and health protocols for COVID-19. As the 700 families of winegrowers typically work in the vineyards alone, they were not affected by the social distancing requirements.

Finances:

- Maintain all jobs held within the company, if necessary, by reallocating employees to work on other tasks

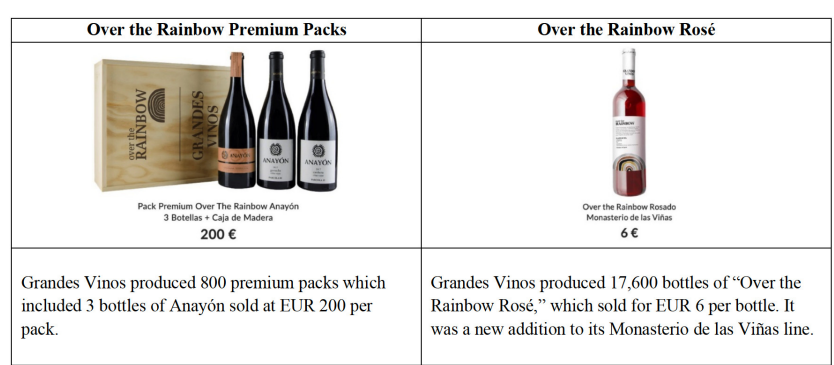

\section{Exhibit 3: Over the Rainbow Products}

Source: Grandes Vinos

experiencing higher demand (for example, to the department charged with preparing online orders).

- Reduce costs wherever possible: re-evaluate service levels according to demand; consolidate sourcing; eliminate low-added-value activities, and review incentive structure within the organization.

- Assist clients as much as possible, whether by affording greater flexibility in terms of payments, relaxing minimum order standards, or any other means of providing assistance in the face of the crisis.

Digital Marketing and Sales:

- Accelerate digital transformation with a special focus on digital marketing and new ways to reach customers more effectively.

- Improve customer relationship management, reviewing emails and social posts and focusing on ecommerce sales.

- Hold virtual tastings in both domestic and export markets. Grandes Vinos partnered with Raúl Igual, winner of the Best Sommelier of Spain contest in 2010 and holder of an Advanced Course of the Court of Master Sommeliers, to conduct detail tastings of 15 wines both in Spanish and English to promote the wines in the different markets and on social media.

- Prepare digital menus using QR codes.

Philanthropy:

- Engage in charitable initiatives such as the "Over the Rainbow." The company also took part on the $\underline{0.19}$ Platform, a fundraising initiative created by the brewing company, Ambar, which aimed to help local bars maintain their employment during COVID-19. As those who were most in danger lived in smaller towns like the Aragón Community.

- Maximize online sales through the "Over the Rainbow" philanthropy initiative.

\section{DISCUSSION}

"Over the Rainbow" was one of the largest corporate philanthropy initiatives in Spain and was one of the projects highlighted in El Gran Retro Solidario (\#Elgranretosolidario), a virtual gala organized by six Spanish NGOs and held on May 2, 2020. It featured celebrities, including top model Judith Mascó, singers Edurne and Eva Amaral, and television presenters such as Jordi Évole. It streamed live 
YouTube and social networks.

These types of initiatives underscored how a company like Grandes Vinos could “do well by doing good.” Its CEO believed that "whatever the final amount that we donate to these organizations, we have become a better company because of the project." There was some preliminary evidence that the "Over the Rainbow" initiative also benefited the company's financial performance. For example, in comparison to the second quarter of 2019, overall revenue had increased by 5.33 percent due to the increase on prices even though its sales volume had declined by 4.99 percent during Q2 2020. Online sales also spiked during the second quarter of 2020, which might be explained in part by the launch of an exclusive online sale tied to the "Over the Rainbow" charity initiative.

\section{CONCLUSION}

This case study analyzed the ways in which Grandes Vi- nos responded to COVID-19, helping its community in the process and adapting its business practices to a new reality. The "Over the Rainbow" initiative entailed the philanthropic contributions to charitable healthcare-related causes by the Grandes Vinos cooperative enterprise. Through this initiative, Grandes Vinos was focused on helping to improve society and stakeholders while at the same time sustaining its own profitability. The health crisis had shown the world the importance of taking all steps possible to fight the pandemic, including corporate philanthropic actions. There were thousands of examples of solidarity efforts such as Grandes Vinos' "Over the Rainbow” initiative. Now, more than ever, we needed the dreams we dream to come true, and this was more likely to happen when firms focused their philanthropic activities on those processes and activities that they perform best. 


\section{REFERENCES}

Carroll, A. B. (1979). A Three-Dimensional Conceptual Model of Corporate Performance. The Academy of Management Review, 4(4), 497. https://doi.org/10.230 7/257850

Carroll, A. B. (1991). The Pyramid of Corporate Social Responsibility: Toward the Moral Management of Organizational Stakeholders. Business Horizons, 34(4), 39-48. https://doi.org/10.1016/0007-6813(91)90005-g

Davis, K. (1960). Can Business Afford to Ignore Social Responsibilities? California Management Review, 2(3), 70-76. https://doi.org/10.2307/41166246

File, K. M., \& Prince, R. A. (1998). Cause related marketing and corporate philanthropy in the privately held enterprise. Journal of Business Ethics, 17(14), 1529-1539. https://doi.org/10.1023/a:1005869 $\underline{418526}$

Godfrey, P. C. (2005). The relationship between corporate philanthropy and shareholder wealth: A risk management perspective. Academy of Management Review, 30(4), 777-798. https://doi.org/1 0.5465/amr.2005.18378878

Gössling, S., Scott, D., \& Hall, C. M. (2020). Pandemics, tourism and global change: A rapid assessment of COVID-19. Journal of Sustainable Tourism, 29(1), 1-20. https://doi.org/10.1080/09669582.2020.175870 $\underline{8}$

Jones, T. M. (1995). Instrumental Stakeholder Theory: A Synthesis of Ethics and Economics. The Academy of Management Review, 20(2), 404. https://doi.org/10.230 7/258852
Lee, S., Singal, M., \& Kang, K. H. (2013). The corporate social responsibility-financial performance link in the U.S. restaurant industry: Do economic conditions matter? International Journal of Hospitality Management, 32, 2-10. https://doi.org/10.1016/j.ijh $\underline{\text { m.2012.03.007 }}$

Over the Rainbow. (2020). Grandes Vinos. https://www.g randesvinos.com/en/rainbow/

Sánchez, C. M. (2000). Motives for corporate philanthropy in El Salvador: altruism and political legitimacy. Journal of Business Ethics, 27(4), 363-375. https://doi.org/10.1023/a:1006169005234

Seifert, B., Morris, S. A., \& Bartkus, B. R. (2004). Having, giving, and getting: Slack resources, corporate philanthropy, and firm financial performance. Business \& Society, 43(2), 135-161. https://doi.org/1 $\underline{0.1177 / 0007650304263919}$

Smith, C. (1994, May). The new corporate philanthropy. Harvard Business Review, 105-116.

Últimos datos oficiales de Covid-19 en España. (2020, July 14). Redacción Médica. https://www.redaccionme dica.com/directo/coronavirus-ultimas-noticias/20200 $\underline{714}$

Wen, J., Kozak, M., Yang, S., \& Liu, F. (2020). COVID-19: Potential effects on Chinese citizens' lifestyle and travel. Tourism Review, 76(1), 74-87. https://doi.org/1 $\underline{0.1108 / \operatorname{tr}-03-2020-0110}$ 